\title{
GLOBALIZATION, GROWTH \& POVERTY ALLEVIATION IN PAKISTAN
}

\author{
Rummana Zaheer \\ Saman Hussain**
}

\begin{abstract}
Globalization hampers the growth level of the countries, then this raising growth rate helps to improve the living standard and reduce inequalities among the masses, that finally downgrade the poverty level of the nations, is the way that global institutions favor it. The debate on rightness of the measures taken for globalization to the socioeconomic development of emerging economies is prolonged and still controversial too. This paper attempts to address the impacts of measures taken for globalization (trade liberalization)specially with reference to its benefits and harms associated to growth and poverty alleviation in Pakistan. In order to examine the effects of trade liberalization on output growth and poverty, Toda-Yamamoto Granger causality is used, by taking data of last 30 years i.e. 1985 to 2015. The empirical findings and review of literature done in the study is consistent with the judgment of prior studies as concluding the hybrid type effects of globalization to the socio-economic conditions i.e. growth and poverty, of Pakistan.
\end{abstract}

Keywords: globalization, trade openness, poverty reduction, economic growth, Pakistan

\section{Introduction}

If you are totally illiterate and living on one dollar a day, the benefits of globalization never comes to you.

$$
\begin{aligned}
& \text { Jimmy Carter (An American politician and 39th president of the } \\
& \text { United States, in } 2002 \text { awarded by Nobel Peace Prize) }
\end{aligned}
$$

Besides the withdrawal of Britain from EU still many of the advocates are in favor of regional integrations and see it as an opportunity of the new integrated block in Continent Europe. In such scenario how it comes to the nations in South Asia? The benefits and harms associated to globalization has not been proved same in its effects in the different regions of the world and being poor, getting the gains of globalization is not an easy path. It is observed that measures supporting the globalization promptly lift up the national output level along reducing the unemployment and income inequalities but in some cases it also could be eyed that besides the benefits, its harms did not allow the nations to raise its growth rate and stand above the poverty line. The net effect of globalization first on growth rate of a country and next to the level of poverty is still controversial among the researchers and unsolved for the policymakers in developing countries.

\footnotetext{
"Rummana Zaheer, Ph.D. Assistant Professor, Department of Economics, University of Karachi

${ }^{* *}$ Saman Hussain, Ph.D Student, Department of Commerce, University of Karachi
} 
Prior to 1980, developing nations were concentrating on protectionism to promote their domestic market. But in 1980s some bilateral and multilateral trade agreements are signed among the developing economies to step towards trade liberalization. Likewise the other developing countries, Pakistan could also be seen interested in adoption of protectionism-free cross border trading policy and serious attempts were taken in 1990s by implementing the reforms in its tariff structure. As under the umbrella of World Bank , International Monetary Fund and U.S. Treasury, many developing nations liberalized their trade patterns by removal of tariff and nontariff costs, removal of interest rate ceiling, deregulation and privatization as the package of Washington Consensus Liberalization of Markets along the adoption of directed policies therein.

The economic globalization i.e. trade liberalization is getting steadily practices in the region of south Asia and like other neighboring countries, Pakistan also shorten its distance towards regional integration by liberalizing its trade routes. Pakistan is the economy, aiming to eradicate poverty, kick out food insecurity along stepping to become more globally integrated market.

The burden to be bearded of non-productive population in Pakistan, is not only contributing to the poverty level but a great hurdle in its way of sustainable development. The measures in the form of trade liberalization remain ineffective and could not give collateral benefits to the growth rate until and unless the poor strata of the economy will not contribute productively to the aggregate output of the country. The openness to trade leads economic growth and the rising growth rate reduces the level of poverty in Pakistan but meanwhile the openness to trade is attributed for the floundering income inequalities in the economy and its harms to those who exist in the bottom of income hierarchy neutralize the benefits associated with the trade led growth. The rising trend of income inequalities suggests that poor will not more be able to share the collateral benefits of globalization. The effects of trade liberalization on the growth rate and poverty level in the economy with reference to Pakistan are debated in this study.

\section{Brief History of Economic Growth}

The economy of Pakistan is typically argued to be subjected to exogenous determinants likewise trade and capital inflows. As the growth history of economy is analyzed, it is found that since early 1950s Pakistan improved its terms of trade but with the end of Korean War its terms of trade collapse resultantly its exports declined by $7 \%$ of GDP and imports declined by $3.6 \% .^{1,2}$ In early 1960 s the export to GDP ratio was $4.5 \%$. Until 1965 pro-US foreign policy surged capital inflows in economy but the war of 1965 debilitate the domestic industry due to this in late 1960s the ratio of export to GDP is declined up to $3.7 \%$.During 1970s the foreign debt raised up to $37 \%$ of GDP and a rise in the unit value index of imports was mainly due to an increase in global commodity price especially wheat and kerosene along increasing cost of exports and finally its

\footnotetext{
${ }^{1}$ Burki. S.J. "Pakistan. Fifty Years of Nationhood", (West View Press, 1999) https://books.google.com.pk/books? $\mathrm{id}=3 \mathrm{nSqBAAAQBAJ} \&$ printsec $=$ frontcover $\&$ source $=$ gbs_ge_summary_r\&cad=0\#v=onepage \&q\&f=false

${ }^{2}$ Husain. I.,'Pakistan The Economy of an Elitist State", (Oxford University Press, 1999) https://www.amazon.com/Pakistan-Economy-Elitist-Ishrat-Husain/dp/0195790146
} 
terms of trade declined by $16.1 \%$. However this study doesn't focus the above regimes as country was facing much deterioration and abnormal economic situation. (In the first three decades the country was merely involved in wars against India i.e. 1948, 1965 and 1971.Thus the data after 1985 seems to be more natural and reliable to address the hypothesis.)

In late 1980s in spite of having a significant raise, the export could not pleasantly affect the current account deficit because of a decline in capital inflows and this situation continues till 1993. ${ }^{3}$ Other significantly affecting factors to growth were devaluation along increasing trend of incentives that typically improved imports instead to nadir the import burden ${ }^{4}$. In late $1990 \mathrm{~s}$, the reforms in the banking sector to raise foreign exchange from the end of foreign remittances surged USD 4 billion in economy.,

In early 2000s Pakistan was the economy that benefitted greatly by the 9/11 and avail the opportunity to readjust its financial relation with World Bank and IMF, and the late 2000s was also good for economy as higher remittances were surged from oil producing countries due to globally high oil prices. (During the regime of global financial crunch of 2008 that was merely started after the insolvency declaration of the Bank Lehman of United States of America.)

The climatic and geographical factors also disturbed the growth level in overall country and raise food insecurity along healthcare issues to the great extent in rural areas. Due to a lack of precautionary measures record breaking floods badly affected the crops all over the country resultantly a severe food shortage hit the rural population and increasing prices were practiced in urban areas (The flood in 2003 badly affected the Sind province due to heavy monsoon rainfall, once again in 2007 Baluchistan, Khyber Pakhton Khwa and Sind faced flood due to a lack of precautionary measures. Further in 2010, a record breaking flood badly affected the crops all over the country. September 2007 brought another devastation on 1.7 million acres of arable land covered with near to reap crop in the form of massive floods in Sind province. September 201, August 2013, and September 2014 disturbed the output yield and raise the food insecurity but in lower intensity as compared the prior). In spite of loss of 1000s lives and million acres of arable lands, Pakistan's economy well establish the slowdowns in manufacturing sector, particularly foreign and domestic portfolio investment and credit disbursement. Since 2011 the GDP of economy raises up to $4.24 \%$ in 2015 as it was aimed to have it at $5.5 \%$.

\footnotetext{
${ }^{3}$ McCartney. M, "Pakistan, Growth, Dependency \& Crisis", The Lahore Journal of Economics, 16(2011): 83

${ }^{4}$ Sarmad. K.(1992),"External Shocks \& Domestic Adjustments in Pakistan 1970-1990", Pakistan Development Review, 31, No.4,(1992):863

${ }^{5}$ Khan. M. A.,Qayyum. A. and Sheikh. S. A., "Financial Development \& Economic Growth", Pakistan Development Review, 44, No.4, (2005):821

${ }^{6}$ Wizarat, Shahida. The Rise and Fall of Industrial Productivity in Pakistan. (Karachi: Oxford University Press, 2002)
} 


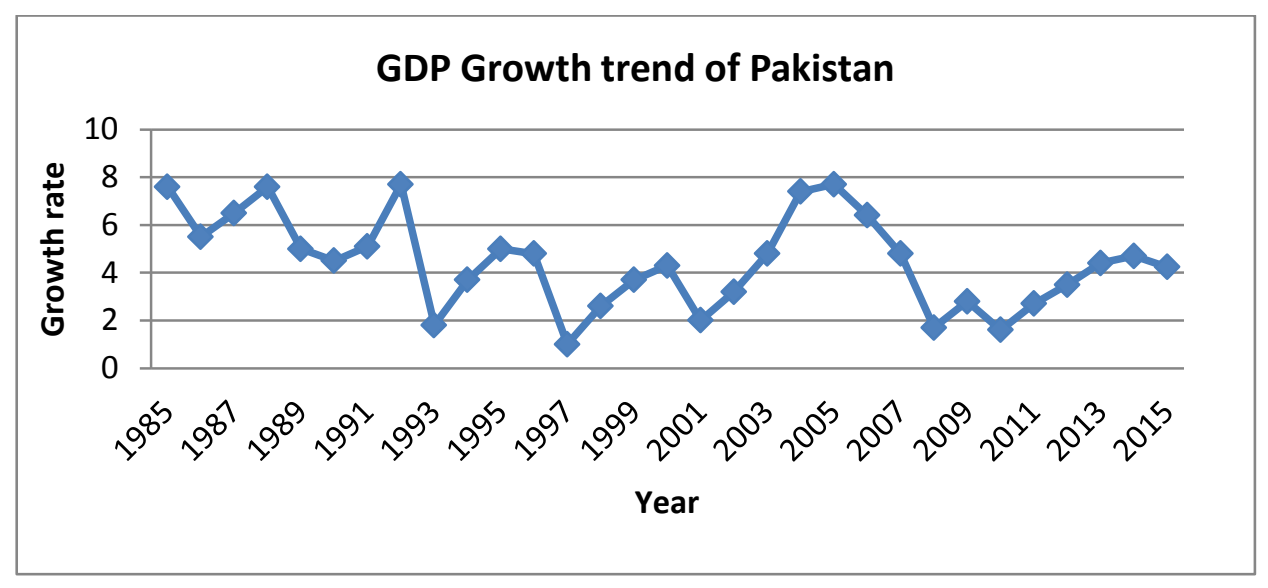

Data Source: World Bank

(The peak rate of GDP growth since 1985 was 7.7 for the year 2005, while the year 1985 and 1988 with $7.6 \%, 1992$ and 2004 with $7.7 \%$ and $7.4 \%$ respectively shown the higher growth rate. In 2008 the economy was on the lower point at growth rate of its history with $1.8 \%$ while the year 1993 with $1.8 \%$ and most terrible the year 1997 with $1 \%$.)

\section{Pakistan's Poverty Trend}

Since 1993 a gradually increase could be eyed in poverty incidence from $21.13 \%$ while in 2003 it got $32.78 \%$ as its highest of the decade. However foreign grants worked to some extent and it declined to $23.9 \%$ in 2004 later on no significant improvement could be observed in upcoming years and still the country has the heavier burden of lower strata at $29.5 \%$ in 2013 as compared to its early years.

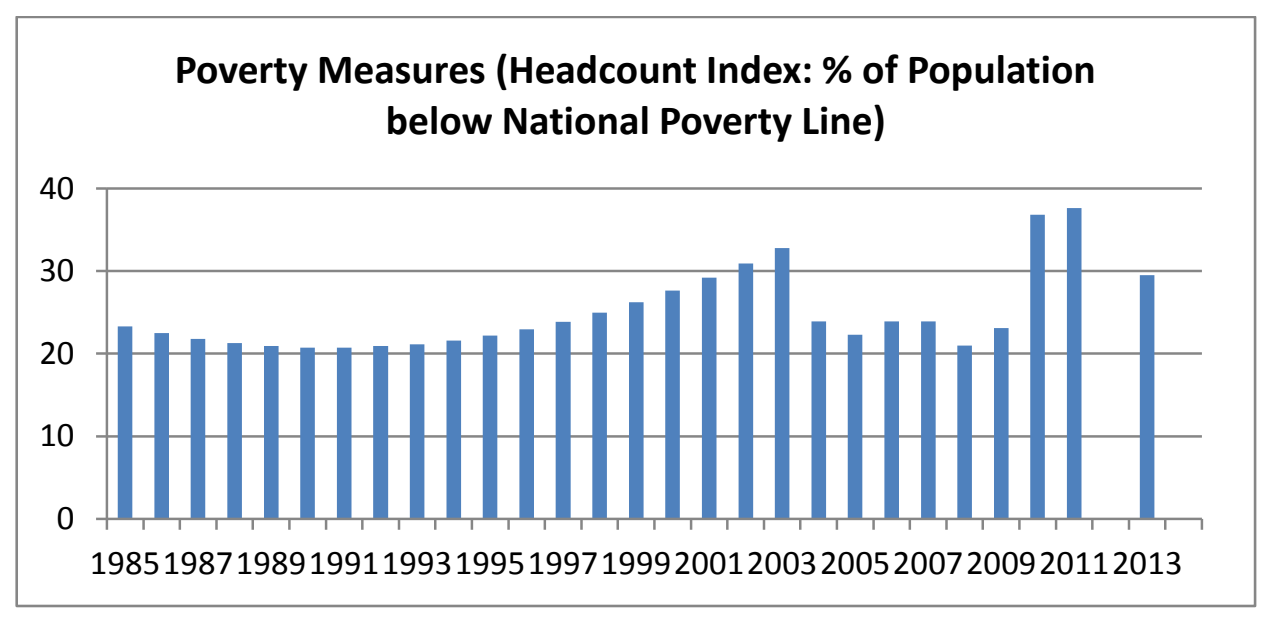


Data source: 1. HCI for the periods of 1985-2003 has been adopted from Jamal.H. 2006); ${ }^{7}$

2. HCI for the periods of 2004-2008 has been adopted from Economic survey of Pakistan and statistical handbook of Pakistan 2010 by SBP;

3. HCI for year 2009 calculated by author with reference to Jamal.H.(2011) (HCI for 2009 increases by $3.63 \%$ with respect to 2005's measures . See Jamal.H.(2011), " Assessing Poverty with Non-income Deprivation Indicators: Pakistan, 2008-09);

4. HCI for the periods of 2010-2014 are adopted from WDI. ${ }^{9}$ (Household Income \& Expenditure Surveys (HIES) are used by researchers for estimation of poverty.)

\section{A Brief History of Trade Liberalization As A Measure of Globalization}

The most liberalization friendly step was seen in 1962 through allowing foreign banks and FDIs. In the era of 70s liberalization again reverted to come front the policy of nationalization. In early of 1980s market based economic strategies were centered. The sector s of oil and gas got lubricated via FDIs along the maximum reduction in tariff by $100 \%$ (except automobile having 250\%).

During the era of 1990s Pakistan exercised the economic liberalization ( the option was not raise domestically formulated policies but a mandatory under the umbrella of IMF and World Bank's structural adjustment program). The sectors prominently benefitted are agriculture, telecommunication and energy. In the early 1990s the rise in export could be eyed at an average of $86 \%$ and till late 90 s due to limited export markets, lower FDIs, not promoting export domestic trading policies, poor infrastructure, poor structural system for trade risk and changes in demand of exports make stagnant the export at US 8 billion dollar.

The growth in trade relative to GDP varies at large in this decade. The growth in trade sector registered a slightly faster rate total output rate. The liberalization process did not alter the other socio-economical indicators to a remarkable extent. Hence the rising trend in openness did not significantly affect the ensuing reduction in poverty level and the upswing of growth rate. The maximum tariff reduction is enjoyed in era as $70 \%$ against 225\% in prior decade along reduction in slabs of 1990s custom duty by 8 and after effects of flexible exchange rate system (This flexible exchange rate system was introduces in the prior decade).

In the beginning of 2000s, many measures has been taken for heightening of exports such as encouragement of exporting high unit value commodities along widening the enhancement to meet the standards internationally. Reduction in cost and vertical integrations are the trends that are seen in domestic market that improve the export competitiveness of Pakistan. The expansion of marketing to explore and access new export market in both product and market diversification are exercised too. For the three

\footnotetext{
${ }^{7}$ Jamal. H.,'Does Inequality Matter for Poverty Reduction? Evidence from Pakistan's Poverty trends", The Pakistan Development Review, 45, No.3(2006):453

${ }^{8}$ Jamal.H.," Assessing Poverty with Non-income Deprivation Indicators: Pakistan, 2008-09” 50, No.4(2011):920

${ }^{9}$ http://databank.worldbank.org/data/reports.aspx?source=2\&country=PAK\#
} 
years it followed the mark by $54.4 \%$ rise at an average and resultantly crossed US 14.1 billion dollar in 2004-05. In terms of economic policies the first seven years of decades are seemed to be more productive and successful. A decline in maximum tariff rate by $55 \%$, reduction in import biases, removal of import quotas, regulatory charges and import duties, opening the economy for FDIs and the international trade via Economic Regulatory Program (EPR) facilitate the state many new agreements to be signed. SAFTA was signed in 12th SAARC Summit and Preferential Trade Agreements (PTAs) with Iran was signed in 2004.FTAs with Sri Lanka also got in operation since 2005(by allowing Sri Lanka to access the 206 products and against it get a duty free access to 10 Sri Lankan products). Early Harvest Program (EHP) with Malaysia and China are signed in 2005. Further FTAs were signed with Malaysia and China in 2007 to widen the trade and economic relationship. PTA also got signed with Mauritius in 2007. Since 2007 export trend grown moderately from about Us 21 billion dollar and reached at around US 30 billion dollar in 2014, showing the growth of 51.36\% in seven years.

The agreements affect import growth more aggressively than export growth and the import growth got a steady velocity as compare to export throughout the trade history. The import growth rate for the period of 1985-1999 was $22.94 \%$, for the period of 19901999 (a whole decade) fallen at $14.26 \%$, more interestingly got affected by the FTAs risen to the benchmark of the history as $216 \%$ for the period of 2000-2009, and till 2014 the pace of growth fallen to $14.5 \%$ and reached at about 46 billion US dollar.

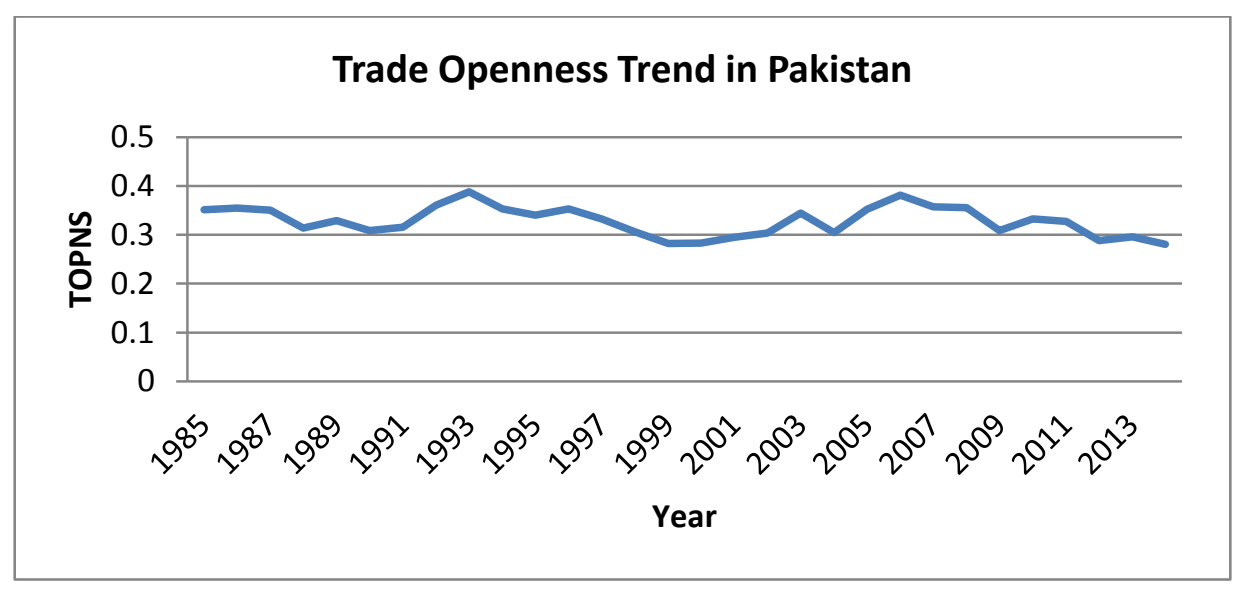

Data Source: World Bank

The interesting fact reveals in the growth and globalization history is that the most of the peak rates belongs to the military regimes, while democracy regimes seemed not significantly affecting both the terms of trade and output yield. The only unaffected sector is of poor that not significantly altered by neither regimes of military nor of democracy. 


\section{Literature Review}

The two different dilemmas based on vision to globalization is discussed by Milanovic (2003) as in his own words:

Globalization being such a huge and multifaceted process presents different faces to different people. Depending on where we live, whether we are rich or poor, where we stand ideologically, we are bound to see the process differently. But this is nothing new. Globalization as it played out from the mid-19th century to 1914 was also a contradictory force, with both its benign and malignant features. Thus, we believe, today too, as in the past, globalization has two faces: the benefits one, based on voluntary exchanges and free circulation of people, capital, goods and ideas; and the other face, based on coercion and brute force. ${ }^{10}$

There are three effects of globalization: the economic, environmental and social. Economically it promotes the growth within, and competition amongst the country / countries. It does not only stimulate the diffusion of technological advancements but same time nadir the volatility of purchasing power. The environmental effects help the economies to promote economic productivity, reallocation of the activities to produce and consume along the usage of environmental friendly technology. The social effects of globalization are in the form of reducing income inequalities via improving labor market along the reduction in poverty. ${ }^{11}$ These three effects of globalization are harmony for the economic development if favored by the economic and socio-political circumstances. The geographical effects of globalization alter the growth level and globalization practices in other countries. ${ }^{12}$

The prominent effects of globalization can be seen in the world as the places having more trade and investment activities do not only rapidly raise the economic growth but an increasing trend of employment has been also observed in the economy as, Harrison attributed the foreign direct investment as a measure of poverty reduction strategy. ${ }^{13}$ Developing countries are increasing their trade shares and nadir their tariffs. If the export is considered as a measure of globalization then the low-income economies are seemed more globalized than those of high-income. The more expanded will be the export activities the less will be the masses under poverty line is a phenomena that observed across the continents. The attribution given to globalization for the growth of an economy is favored by many Pollyannaish's views. Dreher analyzed the 123 countries in a panel by examining the data from 1970 to 2000 and concluded that

\footnotetext{
${ }^{10}$ Milanovic. B. (2003), "The Two Faces of Globalization: Against Globalization As We Know It”, Journal of World Development, 31(4), pp:667-683

${ }^{11}$ Hunter J.W. and Jones T.(2002), “Globalization \&Sustainable Development”, International Review of Environmental Strategies, 3(1), pp.55-6

${ }^{12}$ Killic. C (2015), "Effects of Globalization on Economic Growth: Panel Data Analysis for Developing Countries", Journal of Economic Insights-Trends and Challenges, 4(1). http://www.upg-bulletinse.ro/archive/2015-1/1.Kilic.pdf

${ }^{13}$ Harrison, A. (2006), 'Globalization \& Poverty”, National Bureau of Economic Research. http://www.nber.org/papers/w12347.pdf
} 
globalization not only alters the growth of the economies positively but synergies the domestic markets in global economy. ${ }^{14}$

Afzal and Shaikh \& Shah both favor the economic and financial globalization for the economic development of Pakistan in long run. The significant connection has been found between the financial integration and national development. ${ }^{15,16}$

The attribution is to the rise in reserve of foreign exchange within a country among the many benefits of trade liberalization. The raising earnings of foreign exchange inspires the domestic market to adopt the latest technology in the both forms of services and equipment, to proved their essence to economic growth. ${ }^{17}$

The effects of globalization in the form of capital inflows to the economic growth of a country are not dubious anymore. The developed local financial markets, the extent of openness in trade related strategies along the nature of policies affecting the exchange rate are the factors affecting the collateral benefits of globalization and growth dynamics of a country. The trade liberalization, by granting an attractive environment to the capital inflows, helps to generate the dimensions and cluster of collateral benefits which not only accelerates the growth rate but also boost up the welfare of the nations. ${ }^{18}$ The two way causality relationship is found between trade liberalization and economic growth, ${ }^{19}$ Trade liberalization is not seemed significantly ensuring the economic growth in developing countries without effective macro-economic policies and social stabilization. ${ }^{20}$ As Baghwati \& Srinivasan argued as, if the whole framework of macroeconomic stability is not formulated flexibly the lower standard of living of poor further again hit via raising prices in spite of the presence of free trade routes. ${ }^{21}$ In order to emphasizing the globalization, maintenance of macro-economic stability framework is complementary if equal distribution of relevant benefits among the population's strata is desired.

\footnotetext{
${ }^{14}$ Dreher, A. Does Globalization Affect Growth? Empirical Evidence from a new Index Globalization, (Applied Economics, 2006), 38(10), pp.1091-1110

${ }_{15}$ Afzal, M.(2007), The impact of globalization on Economic Growth of Pakistan, The Pakistan Development Review, 46(4), pp.723-734.

${ }^{16}$ Shaikh, F.M., Shah, M. A., Impact of Globalization on Pakistan's Economy by Using CGE Model, International Conference on Applied Economics - ICOAE, 2008, pp.839-845.

${ }^{17}$ Kemal A.R. (2005) “Income Inequalities in Pakistan \& A Strategy To Reduce Income Inequalities”, Report for the Senate Committee on WTO Implications for Pakistan. http://www.finance.gov.pk/poverty/pakistanincome-inequality-growth.pdf

${ }^{18}$ Ayhan. M.K, Parsad. E, Rogoff. K, and Wei. S, (2006), "Financial Globalization: A Reappraisal”, IMF

Working Paper 06/189. http://www.nber.org/papers/w12484.pdf

${ }^{19}$ Killic. C "Effects of Globalization" Op.cit. (2015),

${ }^{20}$ Rodrick, Dani. "The New Global Economy \& Developing Countries: Making Openness Work.", ODC

Policy Essay No.24. (Washington, DC: Overseas Development Council, 1999).

${ }^{21}$ Bhagwati, J., Srinivasan, T.N. (2001), "Trade and Poverty in the Poor Countries",

http://www.econ.yale.edu/ srinivas/trade_poverty.
} 
One of the many argues against trade liberalization is, it does not ensure the positive growth of economy. The poor countries often seemed fail to well manage the measures and its after affects resultantly adversely affect the rate of growth. ${ }^{22}$

It is good to see that on the one end when world is enjoying the expansion of trading and investment activities then on the other end poverty level also decline surprisingly by $5 \%{ }^{23}$ The prominent effects of globalization can be seen in the world as the places having more trade and investment activities do not only rapidly raise the economic growth but an increasing trend of employment has been also observed in the economy as, Harrison attributed the foreign direct investment as a measure of poverty reduction strategy. ${ }^{24,25}$ Developing countries are increasing their trade shares and nadir their tariffs. If the export is considered as a measure of globalization then the low-income economies are seemed more globalized than those of high-income. The more expanded will be the export activities the less will be the masses under poverty line is a phenomena that observed across the continents. Sometimes unequal income distribution and market disturbances are brought up by trade liberalization that ultimately coerce the living standard of population to the great extent but the dependency of poverty reduction is in proportion of poor in level of employment as trade liberalization raises the demand for labor that ultimately translate it into either in increasing wages or level of employment or the both. Thus by widening and easy access to the opportunities to earn is complementary along globalization for sustainable development of economy. ${ }^{26}$ Prior studies also finds that trade liberalization could significantly boost up the poverty level in country but in long run the impacts of liberalization not only dismay the poverty incidence but bring the upswing in growth rate. ${ }^{27}$

Shehbaz et.al., while analyzing the association between level of poverty and trade liberalization, finds a positive and significant impact of trade liberalization on poverty reduction from the economy in long run, but in short run, efforts done for financial liberalization seems ineffective against poverty alleviation but trade liberalization and economic growth do not reduce the level of poverty. ${ }^{28}$ The emphasis on the measures is necessary to the promotion of foreign direct investment as a complementary factor for

${ }^{22}$ Stiglitz, J. Globalization and Growth in Emerging Markets, The Journal of Policy Modelling. October, Vol.25, (2003), pp:505-524

${ }^{23}$ United Nations Environment Program \& The International Institute of Sustainable Development (UNEP/IISD) Environment \& Trade: A Handbook Stevenage. 2000.

https://www.iisd.org/pdf/envirotrade_handbook.pdf

${ }^{24}$ Harrison, A. 'Globalization \& Poverty”, (National Bureau of Economic Research, 2006). http://www.nber.org/papers/w12347.pdf

${ }^{25}$ India has experienced a reduction in its level of poverty by improving the investment environment for foreign capital inflows in the economy, Mexico is the good example in getting rid of the larger macroeconomic crisis of its history by signing the agreements of regional integration moreover Columbia, Poland and Zambia also the countries enjoying domestically low prices

${ }^{26}$ Ben-David, Dan, Nordstorm H. and Winters, "Trade, Income Disparity \& Poverty”, In WTO Special Studies 5. (Geneva: World Trade Organization, 1999).

https://www.wto.org/english/res_e/booksp_e/special_study_5_e.pdf

${ }^{27}$ Mellor J.W. and Ranade C. "Why Does Agricultural Growth Dominate Poverty Reduction In Low \& Middle Income Countries", The Pakistan Development Review, 45(2), (2006), pp.221-240.

${ }^{28}$ Shahbaz. M. A, Masood. Q.A, Hussain. M.A, and Sabihuddin M.B. (2007), "An Empirical Investigation of Relationship b/w Trade liberalization \& Poverty Reduction: A Case for Pakistan", The Lahore Journal of Economics, 12(1), pp:99-118. 
trade liberalization and earning through the export along this the revolutionized allocation of tax system and direct financing in social sector will be an effective poverty reduction strategy.

Ahmed et.al. ${ }^{29}$ advocate the trade liberalization as it alters the living standards pleasantly, it is not the globalization but that is uneven distribution of income among the masses that gears the population below the poverty line every year. But along this Sharif and Imran,$^{30}$ while discussing the effects of trade liberalization to the poverty and income inequalities in Pakistan, find a negative correlation between trade liberalization and poverty along a week and negative correlation to the income inequalities in short run.

Openness of trading flow reduces the gap between low income market integrating and advanced nations of the world, as nations practicing free trade agreements seemed to grow more rapidly due to their trading structures and readjustments. The phenomena of steadily growth in opened economies, is tied to the flexibility in the system with respect to exchange rate and practice of fiscal discipline. The globalization also magnetize the investment in the field of research. The investment pooled in the enhancement of skills can nourish the capability of economic structures to re-adjust and compete in way of comparative advantage. ${ }^{31}$

The activities promoting exports and import-substitution can also help the economy to lower the poverty incidence and raise economies of scale among the masses. Winters ${ }^{32}$ favors that the route of globalization ultimately raises the standard of living of people. The poor strata not only reduced in ratio in terms of poverty incidence but the access to additional resources also makes them able to uplift their utility level. Sri Nivasan \& Wallack ${ }^{33}$ discusses the sentiments of protectionists as the contributor towards the slow process of economic growth and to a great extent in level of poverty. The continued practice of protectionism domestically not allowed the developing economies to enjoy the potential benefits of regional and international integrations on lower down poverty level.

Having feasible and significant association of measure taken for globalization, still many of the studies do argue against it.

\footnotetext{
${ }^{29}$ Ahmad. N, Luqman. M, Farhat. M.H, and Ahmed. A, "The Impact of Trade Libaralization, Population Growth \& Income Inequality on Poverty: A Case Study of Pakistan", Research Journal of Economics, Business \& ICT, Vol. 5 (2012). http://ojs.journals.cz/index.php/RJEBI/article/view/224/228

${ }^{30}$ Sharif. I. C, and Imran. F, "Does Trade Liberalization reduce poverty and inequality? Empirical Evidence from Pakistan", Pakistan Journal of Commerce \& Social Sciences, 7(3), (2013), pp: 569-587. www.worldbank.org/database http://databank.worldbank.org/data/reports.aspx?source=2\&country=PAK\# www.uncomtrade.org http://comtrade.un.org/data/

${ }^{31}$ Malik S.J. The Guidelines for the Designation of Special Products and Special Safeguard Mechanisms for Pakistan, (Geneva: International Center for Sustainable Trade and Development. 2013)

${ }^{32}$ Winters, L.A. "Trade Liberalization and Poverty”, Discussion Paper No.7 (Poverty Research Unit, University of Sussex, 2000b). http://www.ids.ac.uk/ids/global/pdfs/tlpov.pdf

${ }^{33}$ Srinivasan and Wallack. "Globalization, Growth, and the Poor", The Journal of Policy Modeling. October, 200,4 http://www.econ.yale.edu/ srinivas/Globalization\%20Growth\%20and\%20the\%20Poor.pdf
} 
The global economy bears many opportunities but all are not for all. The rules and regulation to be obeyed by every nation irrespective of their demographical-economic features catalyzed these un equal opportunities for those who already are not competent for their economical survival, and this is not favorable to poor in the globe. ${ }^{34}$ The rules and regulations designed by WTO (World Trade Organization) are compulsion to every nation for their production and cross-border trade. The TRIPS (Trade Related Intellectual Property Rights) ideally equilibrated the social benefits arising from inventions related incentives but practically these things limit the approach of developing nations in order to lowers their patented importation burden. ${ }^{35}$ The efforts done in Pakistan are argued as, being an active member of World Trade Organization, does not facilitate the need of effective utilization of aid that will give robust effects on poverty reduction. The improvement of investment climate, strengthening the human capital, well management of social protection are complementary if a cut down in poverty incidence is desired through trade liberalization. ${ }^{36}$

\section{Objectives of the Study}

The present study aims to address the objectives to explore the association between the trade liberalization and economic growth, to recommend policy implications for the sustainable economic development, and to address the relationship between trade liberalization and poverty alleviation in Pakistan.

\section{Research Methodology}

\section{Data \& Modeling}

This paper analyzes the effects of trade liberalization as a measure of economic globalization on growth rate and poverty level by examining yearly time series data of Pakistan between 1985-2015 period. The variables and symbol used in the analysis are shown in Table-1

Table-1

\begin{tabular}{|l|l|}
\hline Symbol & Variable \\
\hline HCI & $\begin{array}{l}\text { Headcount index measuring poverty } \\
\text { incidence }(\%)\end{array}$ \\
\hline TOPNS & $\begin{array}{l}\text { Trade openness measuring economic } \\
\text { globalization }\end{array}$ \\
\hline GDP_GROWTH & Real GDP growth rate (annual) \\
\hline
\end{tabular}

\footnotetext{
${ }^{34}$ Birdsall. N. “Asymmetric Globalization: Outcomes Versus Opportunities”, Discussion Paper, (2001) .http://www.bc.edu/bc_org/avp/cas/isp/inequality/Asymmetric_Globalization.pdf

${ }^{35}$ Likewise the pharmaceuticals are complementary to health, are not allowed domestically to be copied and produced under TRIPS, and these patented products on economic end increased the cost of imports along decreasing consumer's purchasing power domestically and on the social end increase the social injustice.

${ }^{36}$ Malik S.J. "Globalization and Its Impact on Poverty in Pakistan", A Background Paper for the Pakistan Poverty Reduction Strategy II, (2006)
} 
The data of trade openness is calculated by author, and data used in calculation is obtained from UNComtrade and World Bank Database. Different approaches have been used by researchers to measure the poverty, Headcount index is the measure with the calorific approach addressed in study. Headcount index measures the poverty incidence without respect of its intensity. It estimates the percentage of population living below the national poverty line, while the national poverty line is explained by minimum requirement of calories i.e. $2250 \& 2230$ calories per day per adult for rural and urban inhabitants respectively. The poverty data is obtained from various publications of SPDC and Economic Surveys.

$$
\begin{array}{ccc}
G D P \_G R O W T H & =\beta_{0}+\beta_{1} H C I+\beta_{2} T O P N S+\beta_{3} F D I+\mu \\
\beta_{1}<0 & \beta_{2}>0 & \beta_{3}>0
\end{array}
$$

Where:

$\beta_{0}$ is a constant or y-intercept and $\beta_{1}, \beta_{2}$ and $\beta_{3}$,

are parameters of, $H C I$ as Headcount Index, TOPNS as Trade openness i.e. ratio of sum of sum of exports and imports to GDP and FDI (foreign direct investment), GDP_GROWTH is annual growth rate of gross domestic product and $\mu$ is Error term

\section{Empirical Findings}

The descriptive statistics and correlation matrix is used to check the relation of variables with poverty, is presented in Table-2

Table-2

Descriptive Statistics

\begin{tabular}{|l|r|r|r|r|}
\hline & \multicolumn{1}{|l|}{ FDI } & \multicolumn{1}{l|}{ GDP } & \multicolumn{1}{l|}{ HCI } & \multicolumn{1}{l|}{ TOPNS } \\
\hline Mean & 1.09092 & 4.496429 & 24.91071 & 0.33152 \\
\hline Median & 0.751575 & 4.65 & 23.205 & 0.332926 \\
\hline Maximum & 3.668323 & 7.7 & 37.62 & 0.387704 \\
\hline Minimum & 0.331453 & 1 & 20.71 & 0.282309 \\
\hline Std. Dev & 0.881442 & 2.042599 & 4.765934 & 0.028426 \\
\hline Skewness & 1.808345 & 0.096312 & 1.412714 & -0.00272 \\
\hline Kurtosis & 5.278519 & 1.998583 & 4.030721 & 2.105862 \\
\hline
\end{tabular}

Above table of descriptive statistics represents the nature of the data studied. To address the central tendency of data the tools of mean and median are used, represents the GDP growth rate, Foreign Direct Investment and HCI as positively skewed as their mean is greater than the median while in case of trade openness as the proxy used for the globalization is negatively skewed having the median greater than its mean. 
Table-3

\title{
VAR Granger Causality/Block Exogeneity Wald Tests
}

\author{
VAR Granger Causality/Block Exogeneity Wald Tests Sample: 19852014
}

Included observations: 22

Dependent variable: GDP

\begin{tabular}{|c|c|c|c|}
\hline Excluded & df & Prob. \\
\hline FDI & & 4 & 0.0352 \\
\hline HCI & & 4 & 0 \\
\hline TOPNS & & 4 & 0.0001 \\
\hline All & 70.0237 & 12 & 0 \\
\hline
\end{tabular}

Level of significance is used as 5\% for Toda-Yamamoto Granger Causality

Table-3 represents the causality relationship among the variables. Toda-Yamamoto granger causality is applied at 5\% level of significance. Foreign direct investment as the proxy to financial globalization, HCI as poverty incidence and trade openness as economic globalization cause GDP as the proxy representing economic growth significantly, while there was no reverse causality relationship has been found among the variables.

\section{Conclusion}

The mercuric global economy is responsible for accumulating insecurities raising from socio-psychological costs along increasing consumption standards that are isolated for poor against slightly increasing incomes. The economy of Pakistan if willing to get rid of the associated coerce of globalization i.e. inequalities leading poverty, have to realized its political responsibility more. The study finds after discussion of the existed literature and economy's historical facts and figures that the economic growth in Pakistan no doubted affected by global economy but as more dependent at national factors, domestic trade related policies, climatic and weather situations, and finally governance reforms.

For effectiveness of globalization to the economic bliss of nations, reforms are needed at, (i) global institution that are complementary for rich as well as for poor, (ii) the migration rules, (iii) the trade related rules and the regulations. These all will not only helpful for growth of the Pakistan and emerging world but to nadir the world's poverty too, as legging behind the poor, globalization couldn't bring its blessings to the world. The regional integration is the fruit that must be reaped till the right age. Now the Britain is out of EU isn't mean the last breath of global market but actually it opens the new dimensions for the birth of new globally integrated blocks in the region, and this event isn't the end-initiating globalization but the revolution of it. 


\section{Recommendations}

In order to exploit the regional and global opportunities of globalization in Pakistan, the problem of poverty must be considered seriously. The survival of the economy lies in the boldly taken measures both at domestic government end and at global end. The study suggests:

- $\quad$ To cope up the benefits associated to trade liberalization a well planned tariff policy will be benefited to industrial sector by providence of inputs at cheaper prices.

- The promotion and expansion of micro credit, to facilitates the small and medium sized enterprises domestically that on one end would raise the output yield and next the export and on the other end helps the poor.

- The formulation of such investment policies that create opportunities for entrepreneurship and employment.

- Under the umbrella of globalization the government should promote the inflows of capital by designing of magnetized investment environment.

- The policies for the improvement of human capital in terms of technical and degree education will be effective for raising domestic production and export along the removal of poverty.

- Periodically census needed to be regular to get true estimation of economy's demographic features. This will help out in correct estimation to meet the requirements of population withal raising the effectiveness of developmental strategies. 